execution and interpretation which is unmistakably his. He gave rosonance quantitative significance by his measurements of heats of hydrogenation of unsaturated compounds; with Gomer, he was the first to measure the rate of combination of methyl radicals; he has developed methods for studying very fast reactions and, latterly, by his studies of the reactivity of photochemically produced methylenetype radicals, directed attention to fundamental problems of rate-theory. Light, spectrometers, shock tubes, mass-spectrometers and explosives-the tyiants of many chemists-have been his slaves. He has also been a great public servant in the United States in war and in peace, which fact has been recognized by many awards and has culminated in his present appointment as scientific adviser to President Eisenhower. These are but a fow of his accomplishments, to which one must add his consummate skill in making quartz spiral gauges, as a skier, and raconteur, which, with his vivacity and friendliness, have made him so warmly regarded by students and colleagues from the United States and overseas.

Academician L. D. Landau

Academician L. D. Landau, who has been elected to foreign membership of the Royal Society, is a theoretical physicist with interests in all basic problems of physics regardless of the particular special field in which they arrive. His best-known work includes the theory of the diamagnetism of free electrons, the theory of transitions in atomic collisions, liquid helium, the divergence problems in quantum field theory. He has inspired and trained many distinguished pupils, and the series of textbooks on theoretical physics written by him with E. M. Lifshitz on the basis of his lecture courses have had a profound influence on teaching in the U.S.S.R. He approaches physies with a very personal style, as impatient of pedantic purism as of slipshod physical argument. After working in Leningrad and Kharkov, he has now for many years held a professorship at the Institute of Physical Problems in Moseow.

Marshall Chair of the Physiology of Reproduction, Cambridge : Dr. A. S. Parkes, C.B.E., F.R.S.

Dr. A. S. Parkes, whose appointment to the newly established Marshall chair of the physiology of reproduction in the University of Cambridge has recently been announced, has worked for nearly thirty years in the National Institute for Medical Research, where he is head of the Division of Experimental Biology. Before joining the scientific staff of the Medical Research Council, Dr. Parkes had held a Beit Memorial Fellowship and a Royal Society Foulerton Studentship, and he had, at an early age, established himself as a leading investigator of the physiology of reproduction. His first interest was in ovarian function, knowledge of which was much advanced by his work; in later researches he contributed to most aspects of the physiology of sex hormones. In recent years he has paid much attention to the effects of cold on cells, tissues and the whole animal and, in collaboration particularly with Dr. Audrey Smith and Dr. C. Polge, he has made remarkable observa. tions in this branch of biology. Dr. Parkes has always been alive to the practical applications of his researches; to him is due the method of administration of steroid hormones by tablet implantation, and the work on hypothermia has led to important developments in the storage of erythrocytes, of spermatozoa and of tissues for grafting. Apart fiom his laboratory researches, Dr. Parkes is keenly interested in world population problems. It is indeed appropriate that he should be the first to occupy a chair that bears the name of his former teacher, and which will give him the opportunity to develop a university department devoted to an important branch of physiology.

\section{Educational Co-operation in the Commonwealth}

IN a written answer to a question in the House of Commons on June 24, Mr. R. Thompson, replying for the Minister of State for Commonwealth Relations regarding progress with plans for the award of scholarships under the Commonwealth Scholarship and Fellowship Plan, gave the following information from the Association of Universities of the British Commonwealth. Canada proposes to make ten scholarships tenable from October 1960 and twenty nominations from the United Kingdom have been requested. Offei's of scholarships, tenable from March 1961, for study in Australia have now been made of Commonwealth countries and twenty-five nominations requested from the United Kingdom. New Zealand has announced the offer to other Commonwealth countries of twenty-six scholarships and fellowships tenable at any one time and up to five nominations for scholarships tenable from March 1961 have been requested from the United Kingdom. India has announced the offer of forty-five scholarships and fellowships to various countries of the Commonwealth, and the Federation of Malaya has offered postgraduate awards to more than ten Commonwealth countries, including the United King dom, tenable from May 1961. The Federation of Rhodesia and Nyasaland is offering about five postgraduate scholarships, visiting fellowships and mature awards tenable from Janua:y 1961, and the East African Governments have offered two scholarships, tenable at Makerere College, for which nominations have been requested from the United Kingdom. Pakistan, Ghana and Ceylon also announced offers of scholarships at the Commonwealth Education Conference, but no details are yet available. South Africa had offered a total of twenty scholarships tenable at any one time and five nominations from the United Kingdom had been requested. The Association of Universities of the British Commonwealth proposes to publish a full report of the work done under the Plan at the end of the first year of operation.

\section{Advisory Committee on Nuclear Safety}

AN Advisory Committee on Nuclear Safety has been appointed "To advise the Minister of Power and the Secretary of State for Scotland on any matters affecting the functions of those Ministers in relation to safety under the Nuclear Installations (Licensing and Insurance) Act, 1959, which may be referred to them by either of those Ministers or which in the Committee's opinion ought to be brought to the notice of either Minister, apart from any such reference". Its membership is as follows: Sir Alexander Fleck (chairman); Dr. T. E. Allibone, director of the Associated Electrical Industries Research Laboratory, Aldermaston; Mr. G. F. Bullock, general manager, Vulcan Boiler and General Insurance Co., Ltd., Manchester ; Sir John Cockcroft, Master of Churchill College, Cambridge ; Mr. Patrick Connor, Scottish Divisional Officer of the Amalgamated Engineering Union; Dr. S. C. 